\title{
Structural and optical study of ZnS thin films prepared by radio frequency magnetron sputtering at different substrate temperatures
}

\author{
Le Kong, Jinxiang Deng, Liang Chen, Zhen Shen, Jiyou Wang \\ College of Applied Sciences, Beijing University of Technology, \\ 100124 Beijing, China
}

Received July 3, 2017

\begin{abstract}
ZnS thin films were deposited by radio frequency (RF) sputtering with substrate temperatures from room temperature to $400^{\circ} \mathrm{C}$. The effect of substrate temperature on structural and optical properties for the ZnS films was investigated. The systematic investigation at different substrate temperatures of the properties of sputtered ZnS films especially optical constants obtained through spectroscopic ellipsometry can provide some guidance for ZnS films to be applied in thin film solar cells as buffer layers. The choice of sputtering fabrication method may promote the full sputtering technique route in CIGS or CZTS solar cells which is beneficial to the solar cell industrialization.

Keywords: ZnS thin films, RF magnetron sputtering, Urbach energy, Spectroscopic ellipsometry.

Тонкие пленки ZnS осаждались с помощью радиочастотного (RF) распыления c температурой подложки от комнатной температуры до $400^{\circ} \mathrm{C}$. Исследовано влияние температуры подложки на структурные и оптические свойства пленок ZnS. Исследование при разных температурах подложки оптических свойств напыленных пленок ZnS, методом спектроскопической эллипсометрии может дать некоторые рекомендации для нанесения пленок ZnS на тонкопленочные солнечные элементы в качестве буферных слоев. Данный способ получения пленок может быть использован в солнечных элементах CIGS или CZTS, что выгодно для производства солнечных әлементов.
\end{abstract}

Структурне і оптичне дослідження тонких плівок ZnS, отриманих методом радіочастотного магнетронного розпилення при різних температурах підкладки. Le Kong, Jinxiang Deng, Liang Chen, Zhen Shen, Jiyou Wang.

Тонкі плівки ZnS осаджувалися за допомогою радіочастотного (RF) розпилення 3 температурою підкладки від кімнатної температури до $400^{\circ} \mathrm{C}$. Досліджено вплив температури підкладки на структурні і оптичні властивості плівок ZnS. Вибір способу виготовлення розпилення може сприяти використанню методу повного розпилення в сонячних елементах CIGS або CZTS, що вигідно для індустріалізації сонячних елементів. Систематичне дослідження при різних температурах підкладки властивостей напилених плівок ZnS, особливо оптичних констант, отриманих за допомогою спектроскопічної еліпсометрії, може дати деякі рекомендації для нанесення плівок ZnS на тонкоплівкові сонячні елементи в якості буферних шарів.

\section{Introduction}

II-VI group compound semiconductors are extensively used in opto-electronic devices [1]. CdS has been used broadly as the buffer layer prepared on top of $\mathrm{Cu}(\mathrm{In}, \mathrm{Ga}) \mathrm{Se}_{2}$ (CIGS) absorbers for thin film photovoltaics applications to date and the cell efficiency of $20.3 \%$ was achieved for CIGS solar cells [2, 3]. But further progress 
of efficiency is blocked because CdS has a band gap of $2.45 \mathrm{eV}$ resulting in high absorption at shorter wavelengths $[3,4]$, and CdS contains a toxic element $\mathrm{Cd}$ which is not environment friendly. Some materials with larger band gaps have been considered as possible alternatives, for example $\mathrm{ZnS}$, $\mathrm{In}_{2} \mathrm{~S}_{3}$, ZnSe and (Zn,Mg)O [5]. Among these choices, $\mathrm{ZnS}$ is regarded as one of the most promising materials [6]. Compared with CdS, ZnS is non-toxic, not expensive and plentiful in the world. ZnS is an $n$-type semiconductor with a large direct band gap of $3.2-3.9 \mathrm{eV}$ at ambient temperature [3, 7]. The wide band gap of $\mathrm{ZnS}$ is beneficial for high energy incident photons to enter the absorber layer, and is thus good to improve the blue response of the film solar cells and the cell performance [8]. The efficiency of heterojunction cells relies on the interfacial characteristics between buffer and absorber layer. ZnS possesses good lattice matching with CIGS or $\mathrm{Cu}_{2} \mathrm{ZnSnS}_{4}$ (CZTS) absorbers [3, 9].

Some approaches were reported for the fabrication of $\mathrm{ZnS}$ thin films, for example Radio Frequency Magnetron Sputtering [8], Chemical Bath Deposition [10], Metal Organic Chemical Vapor Deposition [11], Molecular Beam Epitaxy [12], Thermal Evaporation [13]. Magnetron sputtering has some merits compared to the other methods including flexible controllability of the deposition parameters, cost-efficient, high film deposition rate, and particularly the compatibility with the sputtering method of the fabrication of CIGS or CZTS absorbers as well as the window layer giving rise to a full sputtering technique route in solar cells $[3,14,15]$. ZnS thin films were deposited through RF magnetron sputtering at different substrate temperatures in this paper. The effect of substrate temperature on structural and optical properties is studied.

\section{Experimental details}

ZnS thin films were prepared on soda lime glass substrates (15 $\mathrm{mm} \times 10 \mathrm{~mm})$ through RF magnetron sputtering system. At first the substrates were cleaned ultrasonically taking methanol-acetone-methanoldeionized water route and then dried by $\mathrm{N}_{2}$ gas flow. A hot-pressed ZnS target with $60 \mathrm{~mm}$ diameter $5 \mathrm{~mm}$ thickness and $\mathbf{9 9 . 9 9 \%}$ purity stuck to $\mathrm{Cu}$ plate was used during the deposition. The base pressure was $5 \cdot 10^{-4} \mathrm{~Pa}$. The target was pre-sputtered for 10 minutes prior to formal deposition.

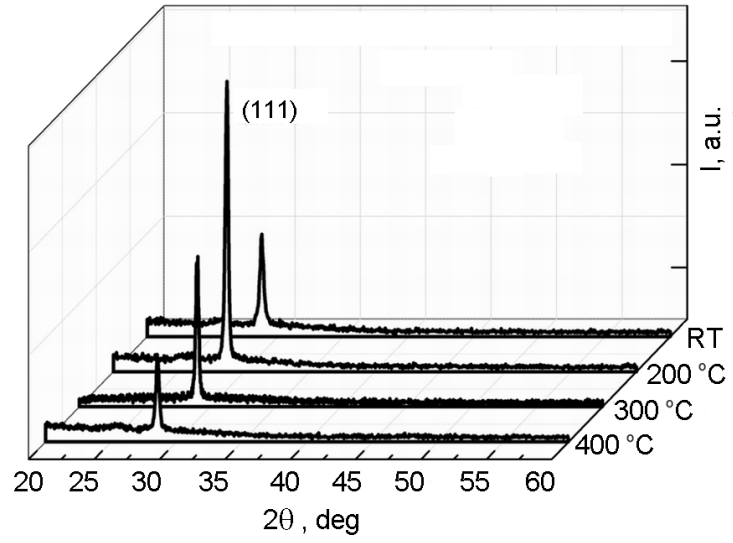

Fig. 1. X-ray diffraction spectra of the ZnS films sputtered at different substrate temperatures from room temperature (RT) to $400^{\circ} \mathrm{C}$.

The working gas was $\operatorname{Ar}(99.999 \%)$ and the working gas pressure was $1.2 \mathrm{~Pa}$. RF power and the distance between target and substrate were fixed at $100 \mathrm{~W}$ and $150 \mathrm{~mm}$, respectively. ZnS films were deposited for an hour at four different substrate temperatures of room temperature $(\mathrm{RT}), 200^{\circ} \mathrm{C}$, $300^{\circ} \mathrm{C}$ and $400^{\circ} \mathrm{C}$ separately. In the sputtering process, the substrate holder was rotating to ensure that the deposition was uniform and the rotational speed was $5 \mathrm{rpm}$.

Structural data and crystallinity of the ZnS films were measured by PERSEE-D3 $\mathrm{Cu}-\mathrm{K} \alpha$ diffraction meter. The morphology was obtained by Scanning Electron Microscope (SEM) (Hitachi-SU8020). The transmission spectra of the samples were performed using Ultraviolet-Visible-Near Infrared spectrometer (Shimadzu-UV3600). The optical constants of the ZnS thin films were measured and analyzed by spectroscopic ellipsometry (Jobin Yvon-MM16).

\section{Results and discussion}

\section{$3.1 X R D$ and $S E M$ results}

Fig. 1 shows the XRD spectra of the ZnS films sputtered at $\mathrm{RT}, 200^{\circ} \mathrm{C}, 300^{\circ} \mathrm{C}$ and $400^{\circ} \mathrm{C}$. The spectra indicates that all the films have (111) plane peak appearing about at $2 \theta=28.5^{\circ}$ and exhibit cubic structure [Joint Committee on Powder Diffraction Standards (JCPDS) card 05-0566]. It can be seen that when the substrate temperature increases from $\mathrm{RT}$ to $200^{\circ} \mathrm{C}$, the XRD peak intensity increases, which means the improvement of the film crystallinity relating to the increase in surface diffusibility of incident sputtered particles. While when the temperature rises from $200^{\circ} \mathrm{C}$ to $300^{\circ} \mathrm{C}$, 


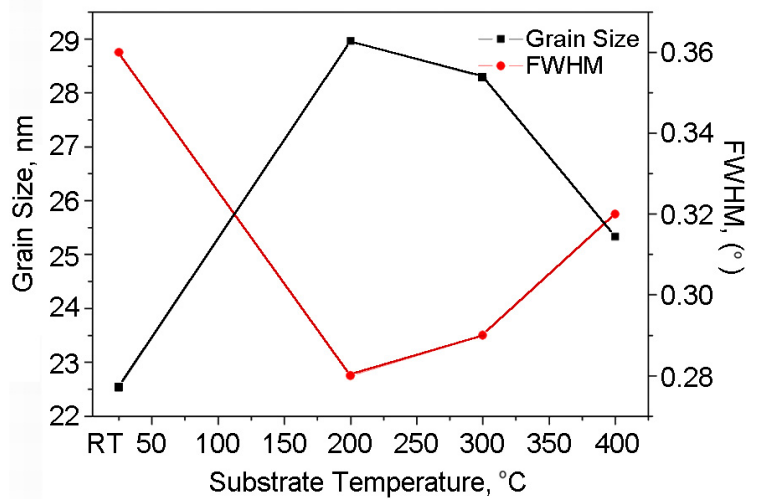

Fig. 2. Mean crystallite size and FWHM of ZnS thin films deposited at different substrate temperatures.

then to $400^{\circ} \mathrm{C}$, the peak intensity keeps decreasing. Subbaiah [16] presented the similar observation when the temperature was beyond $325^{\circ} \mathrm{C}$ and the deterioration of $\mathrm{ZnS}$ films crystallinity was attributed to sulfur re-evaporation, while in our study the deterioration of film crystallinity happened at $300^{\circ} \mathrm{C}$. This temperature difference may be due to the different deposition methods the former is close space evaporation method, while the latter is sputtering method. During film deposition the kinetic energy of incident sputtered particles into substrate is higher than that of evaporated particles so sulfur re-evaporation in sputtering deposition might arise at lower temperature.

The mean crystallite size $D$ was calculated by Scherrer formula:

$$
D=\frac{0.9 \lambda}{\beta \cos \theta},
$$

where X-ray wavelength $\lambda$ is $0.15406 \mathrm{~nm}$, FWHM - full width at half maximum $\beta$ is in radians. The $\boldsymbol{K} \alpha \boldsymbol{2}$ part was eliminated with Jade software.

Basing on data from Fig. 1 the FWHM was obtained and the mean crystallite size was calculated and they are presented in Fig. 2. From RT to $200^{\circ} \mathrm{C}$ the better mobility of sputtered particles at higher temperature brings about better crystallization with less stress resulting in the enlargement of crystallite size. Nevertheless, it is not the same when the substrate temperature grows up to $300^{\circ} \mathrm{C}$ and $400^{\circ} \mathrm{C}$ with decreasing crystallite size. The sulfur vacancy defects might suppress the crystallite growth at the higher temperatures.

Fig. 3 shows SEM images for ZnS films. The large crystal grains may include many
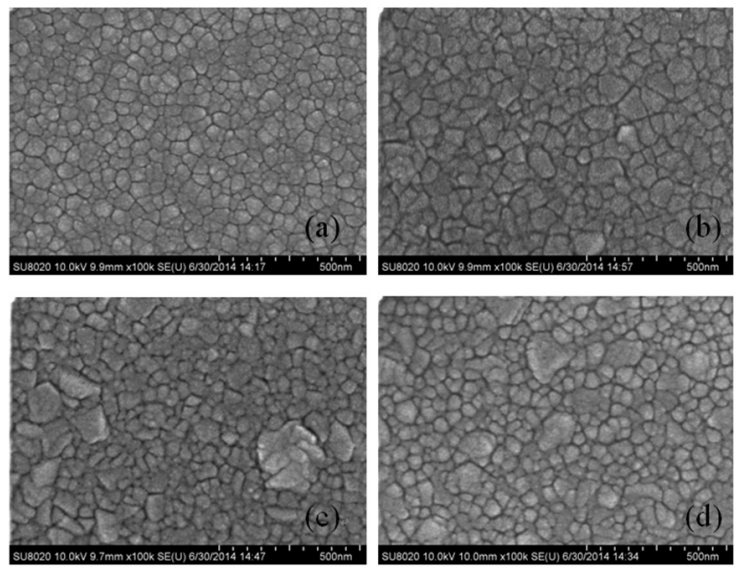

Fig. 3. SEM images of ZnS thin films deposited at different substrate temperatures. (a) $\mathrm{RT}$; (b) $200^{\circ} \mathrm{C}$; (c) $300^{\circ} \mathrm{C}$; (d) $400^{\circ} \mathrm{C}$.

smaller crystallites. The grain size is maximum at $200^{\circ} \mathrm{C}$ substrate temperature which is consistent with the analysis above mentioned.

The lattice constant $(a)$ can be obtained by

$$
a=d \sqrt{h^{2}+k^{2}+l^{2}},
$$

where $h, k$, and $l$ are Miller indices, and $d$ was calculated by Bragg relation $2 d \sin \theta=\lambda$. The calculated lattice constant values of the ZnS thin films are 5.372, 5.387, 5.409, $5.416 \AA$ for substrate temperature RT, $200^{\circ} \mathrm{C}, 300^{\circ} \mathrm{C}, 400^{\circ} \mathrm{C}$ respectively, with some deviations less than $1 \%$ from the standard value $5.406 \AA$ arising from the film stress or defects which affect XRD peak position. All the deposited films showing good lattice matching with CZTS or CIGS absorbers with lattice constant values of about $5.4 \AA$.

\subsection{Transmittance spectrum}

Fig. 4 shows the transmittance spectrum of ZnS films deposited at different substrate temperatures in the wavelength range of 300 to $1200 \mathrm{~nm}$. The straight line in the short wavelength range indicates that the related transitions happen across the band gap directly. The average transmittance is above $80 \%$ in visible and near-infrared wavelengths $(400-1200 \mathrm{~nm})$ for all the films which means high optical transparency in favor of solar cell performance.

\subsection{The Urbach energy of ZnS thin films}

According to the above XRD results, the ZnS films are polycrystalline containing amorphous components. The structural disorder of the material can be characterized through Urbach energy. Near the band edge 


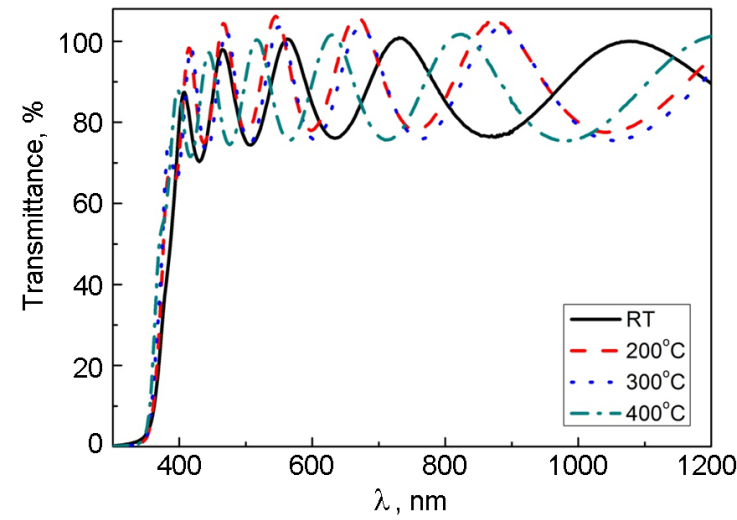

Fig. 4. Optical transmittance spectra of ZnS thin films deposited at different substrate temperatures.

the relation between absorption coefficient $\alpha(\lambda)$ and photon energy is [17, 18]:

$$
\alpha(\lambda)=\alpha_{0} \exp \left(\frac{h v}{E_{0}}\right),
$$

where $\alpha_{0}$ is a constant, $E_{0}$ is the Urbach energy. So there is a linear relationship between $\ln [\alpha(\lambda)]$ and photon energy near the band edge and the Urbach energy $E_{0}$ can be deduced from the reciprocal slope of the linear portion. The $\alpha(\lambda)$ was calculated according to the transmittance spectra data in Fig. 4 with formula $T=\exp [-\alpha(\lambda) d]$, where $T$ is the optical transmittance and $d$ is the film thickness which is about $500 \mathrm{~nm}$ obtained by a Veeco Dektak 150 step profiler. The dependence of $\ln [\alpha(\lambda)]$ on photon energy is shown in Fig. 5, then the deduced Urbach energy $E_{0}$ is presented in Table 1 . From RT to $200^{\circ} \mathrm{C}$, the Urbach energy $E_{0}$ decreases. Then when the substrate temperature rises to $300^{\circ} \mathrm{C}$ and $400^{\circ} \mathrm{C}, E_{0}$ keeps increasing. It indicates the structural disorder variation in the ZnS thin films relating to the $S$ vacancy defects.

\subsection{Optical band gap}

For ZnS films the relation between absorption coefficient $\alpha$ and optical band gap $E_{g}$ can be described by Tauc formula:

$$
\alpha h v=c\left(h v-E_{g}\right)^{m},
$$

where $c$ is a constant, $h v$ is photon energy and $m$ is a constant taking the value $1 / 2$ for $\mathrm{ZnS}$ is the direct band gap semiconductor [16]. The relation curve between $(\alpha h v)^{2}$ and $h v$ for the ZnS films is presented in Fig. 6. The band gap value can be obtained by extrapolating the lin-

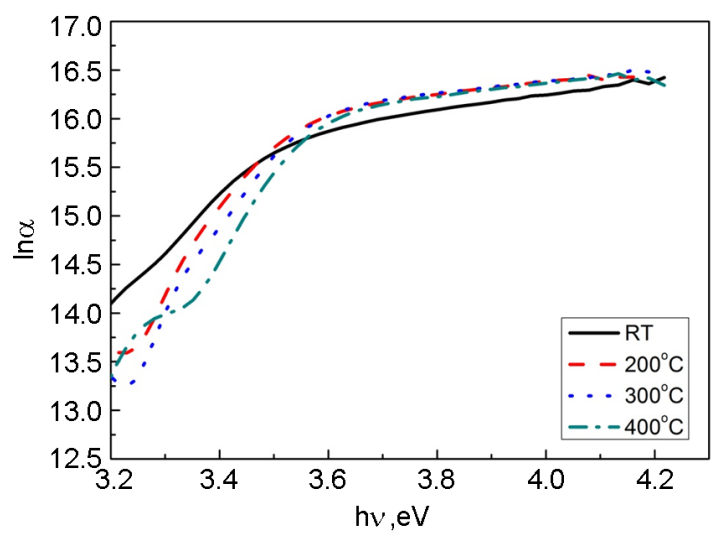

Fig. 5. Dependence of $\ln (\alpha)$ on photon energy.

Table 1. Urbach energy of ZnS thin films deposited at different substrate temperatures

\begin{tabular}{||c|c|c|c|c||}
\hline $\begin{array}{c}\text { Substrate } \\
\text { temperature, }{ }^{\circ} \mathrm{C}\end{array}$ & $\mathrm{RT}$ & 200 & 300 & 400 \\
\hline $\begin{array}{c}\text { Urbach energy, } \\
\mathrm{eV}\end{array}$ & 0.170 & 0.118 & 0.133 & 0.184 \\
\hline
\end{tabular}

Table 2. Optical energy band gap $E_{g}$ of ZnS thin films deposited at different substrate temperatures

\begin{tabular}{|c|c|c|c|c|}
\hline $\begin{array}{c}\text { Substrate } \\
\text { temperature, }{ }^{\circ} \mathrm{C}\end{array}$ & $\mathrm{RT}$ & 200 & 300 & 400 \\
\hline$E_{g}, \mathrm{eV}$ & 3.34 & 3.35 & 3.40 & 3.43 \\
\hline
\end{tabular}

ear portion of the curve to the $h v$ axis. The optical band gap value obtained for the ZnS films rises from 3.34 to $3.43 \mathrm{eV}$ with the increasing substrate temperature $\left(\mathrm{RT}-400^{\circ} \mathrm{C}\right)$, which are given in Table 2. The blue shift of the band gap of ZnS films with increasing substrate temperature could be ascribed to Burstien-Moss effect [16, 19].

\subsection{Refractive index and extinction coeffi- cient}

Spectroscopic ellipsometry is an important method for thin films to analyze optical properties. Ellipsometry can measure the polarization change of reflection light from a sample [20]. The ratio $\rho$ of Fresnel reflection coefficients $r_{p}$ and $r_{s}$ is a complex number and commonly described as $\tan \psi \exp (i \Delta)(\psi, \Delta$ : ellipsometric angles). Refractive index and extinction coefficient can be obtained from the $\psi$ and $\Delta$.

The spectroscopic ellipsometry of the $\mathrm{ZnS}$ films in wavelength range of $430 \mathrm{~nm} \sim$ $850 \mathrm{~nm}$ was measured by phase modulated ellipsometer. In the fitting process Tauc- 


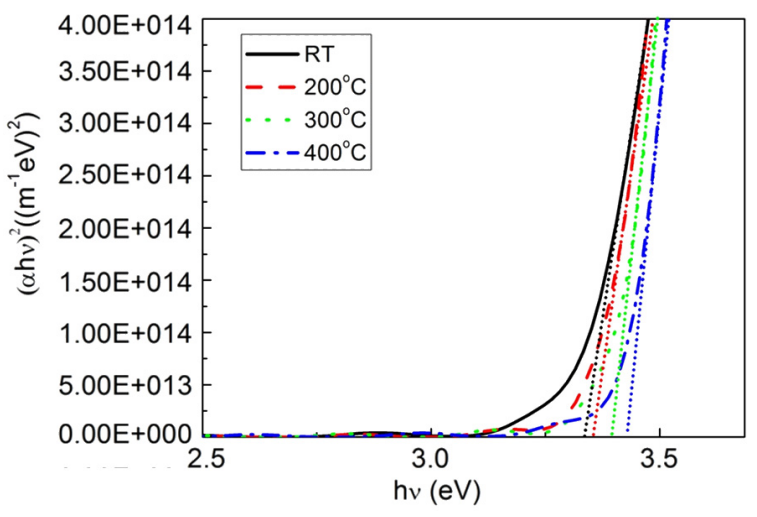

Fig. 6. Variation of $(\alpha h v)^{2}$ with photon energy $(h v)$.

Lorentz dispersion relation model was adopted [21]. The model is derived using Tauc joint density of states above the band edge as well as Lorentz oscillator with electromagnetic radiation. The expression for the dielectric function derived using this model for a single transition is as follows:

$$
\begin{aligned}
& \varepsilon_{i}(E)=\frac{1 A E_{0} C\left(E-E_{g}\right)^{2}}{E\left(E^{2}-E_{0}^{2}\right)^{2}+C^{2} E^{2}}, \\
& \varepsilon_{r}(E)=\varepsilon_{\infty}+\frac{2}{\pi} P \int_{E_{g}}^{\infty} \frac{\xi \varepsilon_{i}(\xi)}{\xi^{2}-E^{2}} d \xi,
\end{aligned}
$$

where $A$ and $C$ are the additional fitting parameters, and $E_{g}$ and $E_{0}$ are the optical band gap and the peak transition energy, respectively. The $\varepsilon_{r}(E)$ is deduced by Kramers-Kronig integration of the $e_{i}(E)$. This model is constrained to $E>E_{g}$ and forced to zero for $E<E_{g}$.

Good ellipsometric fit results for the ZnS thin films have been obtained. Fig. 7 shows the ellipsometric fit for the ZnS thin film deposited at $\mathrm{RT}$ substrate temperature. Refractive index $(n)$ as well as extinction coefficient $(k)$ of all the $\mathrm{ZnS}$ thin films are presented in Fig. 8. The refractive index values vary from 2.1 to 2.4 . The extinction coefficient values are of the order of $10^{-2}$.

The porosity $(P)$ of the films were calculated with the formulas below [22]:

$$
\begin{gathered}
P=1-\frac{\text { bulk density }}{D_{x}}, \\
D_{x}=\frac{4 M}{N_{a} a^{3}},
\end{gathered}
$$

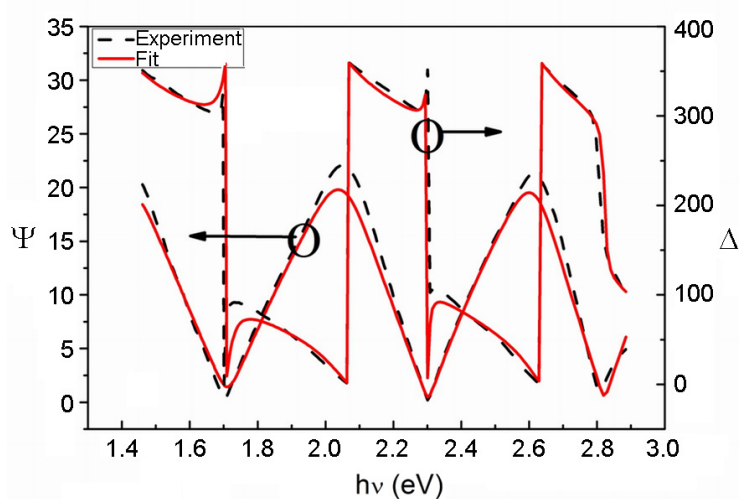

Fig. 7. Ellipsometric fit for the ZnS thin film deposited at substrate temperature of RT.

Table 3. Porosity $(P)$ of ZnS thin films deposited at different substrate temperatures

\begin{tabular}{||c|c|c|c|c||}
\hline $\begin{array}{c}\text { Substrate } \\
\text { temperature, }{ }^{\circ} \mathrm{C}\end{array}$ & $\mathrm{RT}$ & 200 & 300 & 400 \\
\hline $\begin{array}{c}\text { X-ray density }\left(D_{x}\right), \\
\mathrm{g} / \mathrm{cm}^{3}\end{array}$ & 4.176 & 4.142 & 4.090 & 4.072 \\
\hline
\end{tabular}

where $D_{x}$ is the X-ray density and the formula (7) is for a cubical system, $N_{a}$ is Avogadro's number (6.023.10 ${ }^{23}$ atom $\left./ \mathrm{mol}\right)$, $M$ is molecular weight, and $a$ is the lattice constant. The $D_{x}$ of the ZnS thin films was estimated and shown in Table 3 decreasing with increasing substrate temperature. So the porosity (P) of ZnS thin films might decrease with increasing substrate temperature according to the formula (7), resulting in that the packing density of $\mathrm{ZnS}$ thin films increases with increasing substrate temperature. So the refractive index increases with increasing substrate temperature as shown in Fig.8 (a).

The extinction coefficient is influenced by the grain size of thin films. The grain size affects the grain boundary and the light scattering at the grain boundaries. When the grain size becomes larger, the grain boundary increases, the light scattering increases at the grain boundaries, so the extinction coefficient increases. In Fig. 8(b) when the substrate temperature rises to $200^{\circ} \mathrm{C}$ from $\mathrm{RT}$, the extinction coefficient increases, which may be due to the increasing grain size. When the substrate temperature is from $200^{\circ} \mathrm{C}$ to $300^{\circ} \mathrm{C}$ the extinction coefficient decreases due to the decreasing grain size. But when the substrate temperature rises to $400^{\circ} \mathrm{C}$ from $300^{\circ} \mathrm{C}$ the extinction coefficient increases with decreasing 

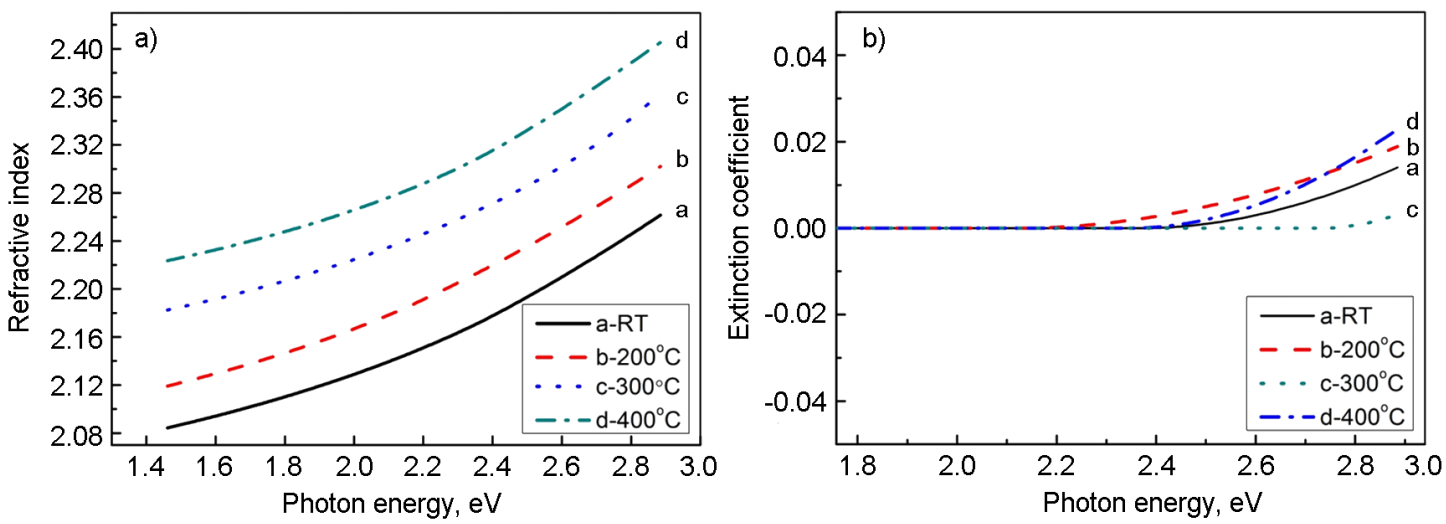

Fig. 8. (a) Refractive index and (b) extinction coefficient of ZnS thin films deposited at different substrate temperatures.

grain size, which may be because the sulfur re-evaporation becomes rather significant resulting in more defects and more extra optical absorption.

\section{Conclusions}

ZnS thin films have been prepared by $\mathrm{RF}$ magnetron sputtering with different substrate temperatures from $\mathrm{RT}$ to $400^{\circ} \mathrm{C}$. The $\mathrm{X}$-ray diffraction spectra indicated all the films had (111) plane appearing about at $2 \theta=28.5^{\circ}$ and exhibited cubic structure. The mean crystallite sizes were calculated by Scherrer formula and reached the maximum of $28.96 \mathrm{~nm}$ at the substrate temperature of $200^{\circ} \mathrm{C}$. The ZnS films deposited show good lattice matching with CZTS or CIGS absorbers and high transparency which is good to be buffer layer material. The energy band gap values rise from $3.34 \mathrm{eV}$ to $3.43 \mathrm{eV}$ with increasing substrate temperatures. The refractive index of the ZnS films is from 2.1 to 2.4 and the extinction coefficient is of the order of $10^{-}$ 2 . The effect of substrate temperature on the optical and structural properties of the ZnS thin films is discussed. These conclusions can provide some guidance for ZnS thin films to be applied in CIGS or CZTS solar cells as buffer layers.

Acknowledgements. Our project was supported by the Funding for the Development Project of Beijing Municipal Education Commission of Science and Technology, China (Grant No. KZ201410005008) and the Natural Science Foundation of Beijing City, China (Grant No. 4102014).

\section{References}

1. V.Kumar, D.K.Dwivedi, Optik, 124, 2345 (2013).
2. P.Jackson, D.Hariskos, E.Lotter et al., Prog. Photovolt. Res. Appl., 19, 894 (2011).

3. P.Chelvanathan, Y.Yusoff, F.Haque et al., $A p$ plied Surface Science, 334, 138 (2015).

4. T.Nakada, M.Mizutani, Y.Hagiwara, A.Kunioka, Sol.Energy Mater.Sol.Cells, 67, 255 (2001).

5. Y.Bouznit, Y.Beggah, A.Boukerika et al., $A p$ plied Surface Science, 284, 936 (2013).

6. D.H.Hwang, J.H.Ahn, K.N.Hui et al., Nanoscale Research Letters, 7, 26 (2012).

7. P.K.Nair, M.T.S.Nair, V.M.Garcia et al., Solar Ener Mater Solar Cells, 52, 313 (1998).

8. M.A.Islam, M.S.Hossain, M.M.Aliyu et al., 7th International Conference on Electrical and Computer Engineering, Dhaka, Bangladesh (2012).

9. S.W.Shin, S.R.Kang, J.H.Yun et al., Sol.Energy Mater. Sol.Cells, 95, 970 (2009).

10. S.Tec-Yam, J.Rojas, V.Rejon, A.I.Oliva, $M a$ terials Chemistry and Physics, 136, 386 (2012).

11. S.Takata, T.Minami, T.Miyata, H.Nanto, Journal of Crystal Growth, 86, 257 (1988).

12. M.M.Islam, S.Ishizuka, A.Yamada et al., Solar Energy Materials \& Solar Cells, 93, 856 (2011).

13. R.A.Bhuiyan, M.M.Alam, M.A.Momin, Turk. J.Phys., 34, 43 (2010).

14. L.X.Shao, K.H.Chang, H.L.Hwang, App.Surf. Sci., 212-213, 305 (2003).

15. X.Liu, H.Cui, C.Kong et al., Appl.Phys. Lett., 106, 131110 (2015).

16. Y.P.Venkata Subbaiah, P.Prathap, K.T.Ramakrishna Reddy, App.Surf.Sci., 253, 2409 (2006).

17. Shuwen Xue, Ceramics International, 39, 6577 (2013)

18. F.Urbach, Physical Review, 92, 1324 (1953)

19. E.Burstein, Phys.Rev., 93, 632 (1954).

20. J.W.Weber, V.E.Calado, M.C.M. van de Sanden, Appl.Phys. Lett., 97, 091904 (2010).

21. D.Datta, S.Kumar, J.Appl.Phys., 106, 074517 (2009).

22. H.R.Shakur, Physica E, 44, 641 (2011). 